Hsiao-Wei Wen · Wlodzimierz Borejsza-Wysocki

Thomas R. DeCory · Richard A. Durst

\title{
Development of a competitive liposome-based lateral flow assay for the rapid detection of the allergenic peanut protein Ara h1
}

Received: 21 March 2005/ Revised: 28 April 2005/ Accepted: 29 April 2005/Published online: 24 June 2005

(C) Springer-Verlag 2005

\begin{abstract}
A competitive lateral flow assay for detecting the major peanut allergen, Ara h1, has been developed. The detector reagents are Ara h1-tagged liposomes, and the capture reagents are anti-Ara h1 polyclonal antibodies. Two types of rabbit polyclonal antibodies were raised either against the entire Ara h1 molecules (antiAra $\mathrm{h} 1 \mathrm{Ab}$ ) or against an immunodominant epitope on Ara h1 (anti-peptide Ab). All of them reacted specifically with Ara h1 in Western Blot against crude peanut proteins. Moreover, the anti-Ara h1 Ab was chosen for this assay development because of its highest immunoactivity to Ara h1-tagged liposomes in the lateral flow assay. The calculated limit of detection (LOD) of this assay is $0.45 \mu \mathrm{g} \mathrm{mL}^{-1}$ of Ara h1 with a dynamic range between 0.1 and $10 \mu \mathrm{g} \mathrm{mL}^{-1}$ of Ara h1 in buffer. Additionally, the visually determined detection range is from 1 to $10 \mu \mathrm{g} \mathrm{mL} \mathrm{L}^{-1}$ of Ara h1 in buffer. Results using this assay can be obtained within $30 \mathrm{~min}$ without the need of sophisticated equipment or techniques; therefore, this lateral flow assay has the potential to be a cost-effective, fast, simple, and sensitive method for on-site screening of peanut allergens.
\end{abstract}

Keywords Ara h1 - Lateral flow assay - Liposomes · Peanuts $\cdot$ Peanut allergen

\section{Introduction}

Peanut allergy is a serious health problem in westernized countries because of its low outgrowth and life-threatening character [1]. Recent studies indicated that

H.-W. Wen · W. Borejsza-Wysocki · T. R. DeCory

R. A. Durst $(\square)$

Department of Food Science and Technology,

Cornell University, 630 West North Street, Geneva,

NY 14456-0462, USA

E-mail: rad2@cornell.edu

Tel : + 1-315-7872297

Fax: + 1-315-7872397 approximately 1 in 150-200 individuals has peanut allergy in these countries [2-4]. Moreover, the prevalence of peanut allergy seems to be increasing, which suggests that peanut allergy is a growing problem $[5,6]$. In a double-blind placebo-controlled food-challenge (DBPCFC) study, mild allergic symptoms were reported with a dose as little as $100 \mu \mathrm{g}$ of peanut proteins [7]. However, no immunotherapy has been successfully developed for treating peanut allergy. The only effective way to prevent adverse allergic reactions is strict avoidance of peanut allergens. Usually, the accidental exposures of peanut allergens are due to the contamination of peanuts in production lines or in raw materials, or the presence of undeclared allergens in products such as cereals, cookies, cakes, and snacks [8]. Therefore, development of a portable, rapid, reliable, and sensitive assay to detect hidden peanut allergens is an urgent requirement. This development can increase food safety for peanut-allergic patients.

The methods to detect peanut contamination can be classified into two groups: protein-based or DNA-based. Protein-based methods either detect major peanut allergens, such as Ara h1 or Ara h2, or detect the entire peanut proteins [9]. Protein-based methods include enzyme-linked immunosorbent assay (ELISA) [10], rocket immuno-electrophoresis (RIE) [11], dot immunoblotting [8, 12], radio-allergosorbent test (RAST) [13], solidphase radioimmuno inhibition assay (RIA) [14], dipstick ELISA [15], and liquid chromatography/tandem mass spectrometry (LC/MS/MS) [16]. The DNA-based techniques detect allergens by amplifying a specific DNA fragment of a peanut allergen gene through the polymerase chain reaction (PCR) [17, 18]. Currently, three DNA-based test formats are available on the market: PCR with gel electrophoresis, DNA-ELISA, and realtime PCR, which are qualitative kits with a detection limit around 10-50 ppm [19, 20]. The majority of commercial protein-based kits are ELISAs with the detection limit between 0.1 and $5 \mathrm{ppm}$. Even though these assays can precisely detect peanuts, some assays need expensive equipment, such as a micro-plate reader or thermocy- 
cler, and all need well-trained people to operate them. The lateral flow assay is a simplified version of ELISA with a nitrocellulose membrane strip, on which immunoreactants such as antibodies or antigens are applied $[21,22]$. This type of assay is easy to operate, and its result can be visually interpreted or quantitatively measured by densitometry with computer scanning or a handheld reflectometer. Recently, only two lateral flow assays for detecting peanuts have been placed on the market, and both are the sandwich assay format [20,23]. In this study, a competitive lateral flow assay has been developed for specifically detecting a major peanut allergen-Ara h1. The Ara h1 is a 63.5-kDa glycoprotein that comprises $12-16 \%$ of total peanut proteins, and has a high frequency of sensitization up to $100 \%$ of peanut-sensitized patients [24]. In addition, Ara h1 can form a stable trimeric structure, which can protect it from degradation due to food processing or enzymes from the gastrointestinal tract $[25,26]$. Because of this allergenicity preservation, Ara $\mathrm{h} 1$ is an appropriate marker to identify peanut contamination in foods or production lines.

Liposomes are spherical nanovesicles composed of one or several phospholipid bilayers surrounding an aqueous cavity [27]. In this study, hundreds of thousands of molecules of a red dye marker, sulforhodamine B (SRB), are captured inside cavities of liposomes. This large amount of SRB allows liposomes to be visually detected immediately without further processing [28]. In addition, liposomes are very stable and can be used in field-portable or point-of-care sensor systems [29]. Moreover, a variety of biological ligands, such as peptides, hormones, antibodies, sugars, and nucleic acids, can be conjugated to the surface of liposomes, and these ligands make the liposomes targeted.

In this study, maleimide-modified Ara h1 molecules were covalently conjugated to sulfhydryl groups on the liposome surface to form Ara h1-tagged liposomes used as the detector reagent. Free Ara h1 molecules in the sample competed with Ara h1-tagged liposomes for binding to the limited number of anti-Ara $\mathrm{h} 1$ antibodies in the test line on the strips. Samples containing larger amounts of Ara h1 would show lower signals on the test line. The aim of this study was to develop and optimize a rapid, portable, and easy-to-read lateral flow assay for the detection of the major peanut allergen-Ara h1.

\section{Experimental}

\section{Reagents and materials}

Raw peanuts were purchased from a local food market (Geneva, NY, USA). High Q cartridge, Methyl HIC (hydrophobic interaction chromatography) cartridge, Protein 6 cartridge, and Protein A cartridge were purchased from BioRad (Hercules, CA, USA). Dipalmitoylphosphatidylcholine (DPPC), dipalmitoylphosphatidylethanolamine (DPPE), dipalmitoylphos- phatidylglycerol (DPPG), 1,2-dipalmitoyl-sn-glycero-3phosphoethanolamine N-(cap biotinyl) (DPPE-biotin), and the Mini Extruder were purchased from Avanti Polar Lipids, Inc. (Alabaster, AL, USA). Hydroxylamine hydrochloride, $\quad N$-succinimidyl- $S$-acetylthiopropionate (SATA), sulfosuccinimidyl-4- $N$-maleimidomethyl cyclohexane-1-carboxylate (sulfo-SMCC), $N$-ethylmaleimide (NEM) and Blocker Casein were purchased from Pierce (Rockford, IL, USA). Poly(vinyl difluoride) (PVDF) membranes and HF 120 nitrocellulose (NC) membranes were bought from Millipore (Bedford, MA, USA). Polycarbonate (PC) membranes of 0.2 - and $0.4-\mu \mathrm{m}$ pore size came from Whatman International Ltd. (Maidstone, UK). Anti-rabbit $\operatorname{IgG}$ ( $\mathrm{Fc}$ fragment specific) alkaline phosphatase conjugates and 5-bromo-4-chloro-3-indoxyl phosphate/nitro blue tetrazolium (BCIP/NBT) substrates were purchased from Promega (Madison, WI, USA). The NC membranes (AE100, AE 99, FF 85 and Prima 85), type 900 wicking paper, and conjugate pads (8S, 12S, 16S and 33 Glass) were supplied by Schleicher and Schuell (Dassel, Germany). Goat serum was from Quad Five (Ryegate, MT, USA). All other chemicals were purchased from Sigma (St. Louis, MO, USA).

\section{Purification and identification of Ara h1}

Raw peanuts were first ground and then defatted with acetone. Crude peanut proteins were then extracted by mixing $40 \mathrm{~g}$ of the defatted peanut powder with $1 \mathrm{~L}$ of extraction buffer (50 mM Tris, $\mathrm{pH} 8.3,1 \mathrm{mM}$ ethylenediaminetetraacetate (EDTA), $5 \mathrm{mM}$ dithiothreitol (DTT), $200 \mathrm{mM} \mathrm{NaCl}$, and $0.13 \% \mathrm{v} / \mathrm{v}$ protease inhibitor cocktail for plant cell extracts) at $4^{\circ} \mathrm{C}$ for $4 \mathrm{~h} \mathrm{[25].} \mathrm{The}$ crude peanut proteins were purified from the $70-100 \%$ saturated ammonium sulfate (AS) fraction, and then dialyzed overnight against $50 \mathrm{mM}$ Tris buffer supplemented with $1 \mathrm{mM}$ EDTA and $5 \mathrm{mM}$ DTT $(\mathrm{pH} 8.3)$ at $4^{\circ} \mathrm{C}$. The dialyzed peanut protein solution was purified in a High Q cartridge with a linear salt gradient $(0-500 \mathrm{mM}$ $\mathrm{NaCl})$. Fractions containing Ara h1 were further purified in an HIC cartridge with a linear salt gradient $(2-0 \mathrm{M}$ ammonium sulfate). Protein concentration was determined by Bio-Rad protein assay with bovine serum albumin (BSA) as the standard. Further identification of purified Ara h1 was investigated by $\mathrm{N}$-terminal sequencing with the Edman reaction, and peptide mapping with matrix-assisted laser desorption/ionization time-of-flight (MALDI-TOF) mass spectrometry [30]. Both analyzes were processed by the Protein Core Facility, Johns Hopkins University, Baltimore, MD, USA.

Production and characterization of antibodies against Ara h1

Antibody production was carried out by AnaSpec Inc. (San Jose, CA, USA). Two kinds of immunogens were used to raise antibodies against Ara h1: purified Ara h1 
and peptide KLH (keyhole limpet hemocyanin). An amount of $100 \mu \mathrm{g}$ of purified Ara h1 was run in a sodium dodecyl sulfate-polyacrylamide gel electrophoresis (SDS-PAGE) gel, and the bands containing Ara h1 were used for the immunization of two New Zealand White rabbits (R2307 and R2308). For producing antibodies against peptide KLH, a synthetic peptide with the sequence CSNREVRRYTARLKEG- $\mathrm{NH}_{2}$ was chosen based on the expected antigenicity, synthesized, conjugated with KLH, and injected into two New Zealand White rabbits (R2149 and R2150). The antibodies from four batches of sera (R2149, R2150, R2307, and R2308) were purified through a protein A cartridge, according to the procedure as described by the supplier (Bio-Rad).

\section{SDS-PAGE and Western blot}

The SDS-PAGE was performed in a Bio-Rad Mini Protean II system with $10 \%$ acrylamide gel or precast $4-20 \%$ Tris-glycine gel [31]. Gels were stained with Coomassie Brilliant Blue G-250. For the Western Blot, proteins from the gel were transferred into the PVDF membrane at $100 \mathrm{~mA}$ for $1 \mathrm{~h}$, as described by Towbin et al. [32]. Membranes were blocked with $5 \%$ (w/v) nonfat dried milk in $10 \mathrm{mM}$ Tris (pH 7.5), $150 \mathrm{mM} \mathrm{NaCl}, 0.05 \%$ Tween-20 (TBST) for $1 \mathrm{~h}$ at room temperature. Antibody solutions against Ara h1 were diluted to $100 \mathrm{ng} \mathrm{mL}^{-1}$ in TBST, and incubated with the membrane for $1 \mathrm{~h}$ at room temperature. After washing with TBST, bound antibodies were detected using anti-rabbit IgG conjugated to alkaline phosphatase. The membrane was washed again with TBST, and the captured anti-rabbit IgG complexes were visualized by the addition of BCIP/NBT as described by the supplier (Promega).

\section{Indirect ELISA}

In the ELISA, the microwell plate was coated with $100 \mu \mathrm{L} /$ well of $125-500 \mathrm{ng} \mathrm{\textrm {mL } ^ { - 1 }}$ Ara h1 diluted in phosphate-buffered saline (PBS: $10 \mathrm{mM}$ phosphate, $150 \mathrm{mM} \mathrm{NaCl}, \mathrm{pH} \mathrm{7.5)}$, and incubated at $37^{\circ} \mathrm{C}$ for $1 \mathrm{~h}$. Two hundred $\mu \mathrm{L} /$ well of $5 \%(\mathrm{w} / \mathrm{v})$ BSA in TBST was added for blocking at $37^{\circ} \mathrm{C}$ for $1 \mathrm{~h}$. After washing, $100 \mu \mathrm{L} /$ well of $1 \mu \mathrm{g} \mathrm{mL}^{-1}$ antibodies against Ara h1 was added and incubated at $37^{\circ} \mathrm{C}$ for $1 \mathrm{~h}$. The bound antibodies were detected by incubation with the diluted 1:20,000 goat anti-rabbit $\mathrm{IgG}$ horseradish peroxidase (HRP) conjugators at $37^{\circ} \mathrm{C}$ for $1 \mathrm{~h}$, and then with HRP substrate. The reaction was terminated by the addition of $50 \mu \mathrm{L} /$ well of $2 \mathrm{M} \mathrm{H}_{2} \mathrm{SO}_{4}$, and absorbance was measured at $450 \mathrm{~nm}$. Between each step, plates were washed thoroughly three times with TBST.

\section{Preparation of Ara h1-tagged liposomes}

Liposomes were prepared by a hydration/freezing and thawing/extrusion method [33]. First, DPPE-ATA was prepared by conjugating DPPE to SATA as described previously [34]. The mixture of DPPC, DPPG, cholesterol, DPPE-biotin, and DPPE-ATA, in a molar ratio of 43:5:45:3:4, was dissolved in a solution of $6 \mathrm{~mL}$ chloroform, $1 \mathrm{~mL}$ methanol, and $0.5 \mathrm{~mL}$ DPPE-ATA, and dried on a rotary evaporator. The dried lipid film was hydrated by the addition of $3 \mathrm{~mL}$ of $0.15 \mathrm{M}$ SRB solution (in $0.02 \mathrm{M} \mathrm{N}$-2-hydroxyethylpiperazine $\mathrm{N}$-2ethanesulfonic acid (HEPES), pH 7.5, osmolality $535 \mathrm{mmol} \mathrm{kg} \mathrm{kg}^{-1}$ ). The lipid solution was processed with five freeze/thaw cycles, and then extruded through 0.4and $0.2-\mu \mathrm{m}$ pore-size PC membranes. Unencapsulated SRB was removed by gel filtration using a Sephadex G50 column with Tris-buffered saline (TBS: $0.02 \mathrm{M}$ Tris with $\left.0.15 \mathrm{M} \mathrm{NaCl}, 0.01 \% \mathrm{NaN}_{3}, \mathrm{pH} 7.5\right)$ containing

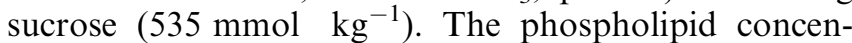
tration of the liposomes was determined by Bartlett's phosphorus assay [35], and the size of the liposomes was measured by laser diffraction particle size analysis in an LS particle size analyzer (Coulter Scientific Instruments, Hialeah, FL, USA).

Ara h1-tagged liposomes were produced by conjugating maleimide-derivatized Ara h1 to the activated liposomes. Briefly, sulfo-SMCC was added to Ara h1 at a molar ratio of 15/1 (sulfo-SMCC/protein), and incubated at $37^{\circ} \mathrm{C}$ for $30 \mathrm{~min}$. Maleimide-derivatized Ara h1 was purified through a P6 cartridge with PBS buffer. Liposomes were deprotected by $500 \mathrm{mM}$ hydroxylamine at a molar ratio of 30/1 (hydroxylamine/DPPE-ATA) at room temperature for $2 \mathrm{~h}$, and then incubated with derivatized Ara $\mathrm{h} 1$ at $4^{\circ} \mathrm{C}$ overnight. To quench the remaining thiol groups, liposomes were treated with $100 \mathrm{mM} N$-ethylmaleimide at room temperature for $2 \mathrm{~h}$. Ara h 1-tagged liposomes were separated from unbound Ara h1 thorough a Sepharose CL-4B column with TBS containing sucrose $\left(535 \mathrm{mmol} \mathrm{kg} \mathrm{kg}^{-1}\right)$.

\section{Preparation of test strips}

The test strip consisted of a laminated card, containing a layer of adhesive, on which the NC membrane, conjugate pad, and absorbent pad were pasted (Fig. 1). On a strip, $4 \mu \mathrm{g} \mathrm{cm}^{-1}$ of the antibody against Ara h1 was coated in a test line $(2.0 \mathrm{~cm}$ from the proximal end $)$, and $0.5 \mu \mathrm{g} \mathrm{cm}^{-1}$ avidin was coated in a control line $(2.5 \mathrm{~cm}$ from the proximal end) using a Linomat IV TLC Applicator (Camag Scientific, Wrightsville Beach, NC, USA). The membrane was dried at $37^{\circ} \mathrm{C}$ for $30 \mathrm{~min}$ in a ventilated convection oven, and stored under dry conditions (desiccant) at room temperature until used. The conjugate pad was pre-treated with a mixture of $5 \mathrm{mM}$ sodium tetraborate, $4 \%$ BSA, $3 \%$ goat serum, $1 \%$ PVP [poly(vinyl pyrrolidone), MW $10 \mathrm{kDa}$ ], and $0.002 \%$ Triton X-100 (pH 8.0) for $5 \mathrm{~min}$, and then dried at $37^{\circ} \mathrm{C}$ for $1 \mathrm{~h}$. In all assays, Schleicher and Schuell (S\&S) type 900 cotton linter paper was used as the absorbent pad. In assembling, the $\mathrm{NC}$ membrane was first attached to a laminated card and rolled to remove trapped air by 
a

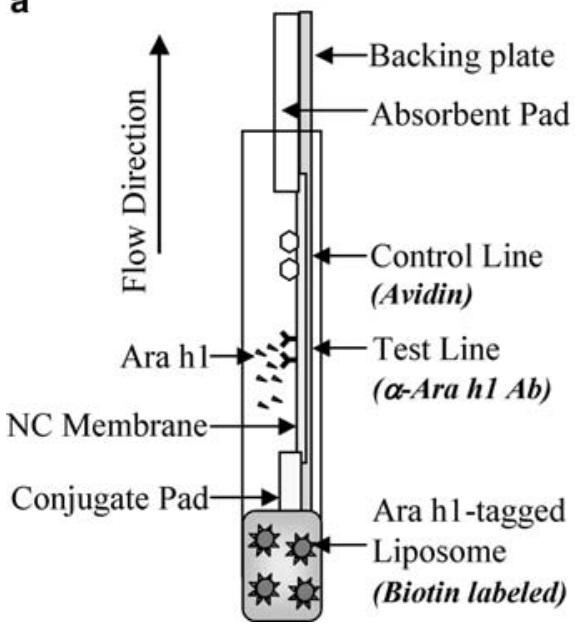

b Condition A: No Ara h1

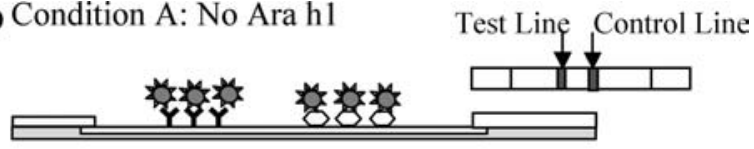

Condition B: Small Amount of Ara h1

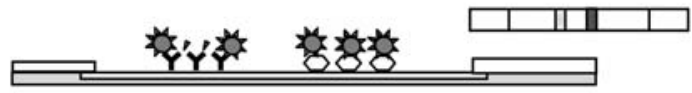

Condition C: Excess Ara h1

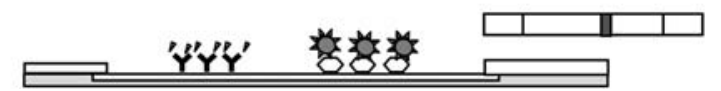

Fig. 1 Competitive lateral flow assay format. a Diagram of a test strip showing a side-view of its components. b Principle of a competitive test strip assay with Ara h1-tagged liposomes

using a small wooden brayer. The absorbent pad was adhered to the upper end of the test strip with $0.1 \mathrm{~cm}$ overlapping the NC membrane. The blocked conjugate pad was placed at the opposite end of the test strip with $0.3 \mathrm{~cm}$ overlapping the NC membrane. After assembling, the whole set of components was cut into $5-\mathrm{mm}$ strips.

\section{Assay format}

The sample solution $(20 \mu \mathrm{L})$ was placed in a glass tube $(12 \times 75 \mathrm{~mm})$, and then a test strip was inserted into this tube. After sample solution was absorbed (about $2 \mathrm{~min}$ ), a mixture of $10 \mu \mathrm{L}$ Ara h1-tagged liposomes and $10 \mu \mathrm{L}$ Blocker Casein ( $1 \%$ casein in TBS) was added to the same glass tube allowed to be absorbed, followed by the addition of $50 \mu \mathrm{L}$ Blocker Casein. Once the Blocker Casein solution was absorbed into the strip (about $20 \mathrm{~min}$ ), the test strip was taken out. The signal intensity of the test line was qualitatively estimated visually, or quantitatively measured by conversion into gray scale readings. First, the test strips were scanned using an Epson Expression 636 color image scanner (Torrance, CA, USA), and the scanned images were converted into gray scale readings by Scan analysis densitometry software (Biosoft, Ferguson, MO, USA). When the assay is performed properly, the control line is always visible above the test line.

\section{Results and discussion}

Purification and identification of Ara h1

In 1916, Johns and Jones isolated two globulins from peanuts by AS fractional precipitation, and named them as arachin and conarachin [36]. More than seven decades later, Burks and his colleagues isolated, purified, and characterized a major peanut allergen-Ara h1 [37]. In this study, the modified Burks' method was used to isolate Ara h1 from raw peanuts. The purification of Ara h1 was monitored by SDS-PAGE as displayed in Fig. 2. During the purification, the purity of Ara h1 (MW $63.5 \mathrm{kDa}$ ) increased from around $20 \%$ (lane 1) to about $95 \%$ of total peanut proteins (lane 4). The molecular weight of this purified Ara h1 is the same as that isolated by Burks [37].

To confirm the identity of the purified Ara h1, the band containing proteins with a molecular weight of $63.5 \mathrm{kDa}$ was cut out and subjected to peptide mapping and N-terminal sequencing. The first theoretical amino acid sequence of Ara h1 was published by Burks et al. [38]. In this study, comparison of the measured and calculated peptide masses resolved 33 peptides with high match score $\left(2.342 \times 10^{11}\right)$. These peptides covered $43 \%$ of deduced amino acid sequence of clone $\mathrm{P} 41 \mathrm{~B}$ precursor of Ara h1, as shown in Fig. 3. This figure also indicated the

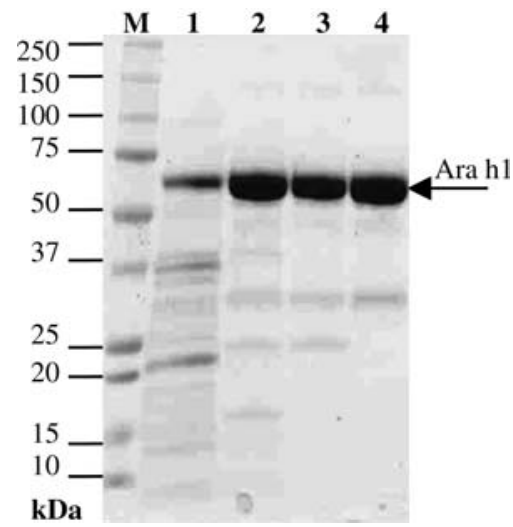

Fig. 2 SDS-PAGE of each step of the overall purification process of Ara h1. The purification steps were the extraction of total peanut proteins (lane 1), 70-100\% AS fractionation (lane 2), ion-exchange chromatography on High Q column (lane 3), and hydrophobic interaction chromatography on $\mathrm{HIC}$ column (lane 4). Lane $M$ contained pre-stained protein standards. The gel was stained with Coomassie brilliant blue $\mathrm{G} 250$ 
Fig. 3 Amino acid sequence of Ara h1 from clone P41B precursor. Amino acids written as capital letters were identified from $\mathrm{N}$-terminal sequencing, and the highlighted amino acids were found by peptide mapping analysis

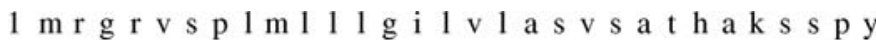
$31 \mathrm{qkkt}$ e n p c a q c l q s c q q e d d l k q k a c e s $61 \mathrm{rct} k \mathrm{l}$ e y d p r c v y d p r g h t g t t n q RS P PGE 91 R T r g r q p g d y d d d r r q p r r e e g g r w g p a g p 121 r e r e r e e d w r p r e dw r r p s q q p r k r p e $151 \mathrm{~g} \mathrm{regeqewgt}$ p g s h v e e t s r n p f y f p t 181 r f s t r y g n q g r i r v l q r f d q r s r f q n l q $211 \mathrm{nhr}$ i vq i a k p t l v l pkhadadn i l vi q q $241 \mathrm{gqa}$ t v t vangnn r s f n l d e g a $1 \mathrm{r}$ i ps g f 271 i s y i l n r hdnqn l r vaki smpvntpgqfed $301 \mathrm{f} f \mathrm{pas} s \mathrm{r}$ q s s y $1 \mathrm{qg}$ f s r n $\mathrm{l}$ e a a $\mathrm{n}$ a e $\mathrm{f}$ 331 e i r r 11 e e naggeqe e rg q r w t r s s e n $361 \mathrm{neg}$ v i vkvske hve e l t k h a k s sk kg e e 391 e g d i t n p i n l r e g e pd l s n n f g l f e vkpd $421 \mathrm{k} \mathrm{k} \mathrm{n} \mathrm{p} \mathrm{q} 1 \mathrm{qd} 1 \mathrm{dmmlt} \mathrm{c} \mathrm{ve} \mathrm{i} \mathrm{k} \mathrm{e} \mathrm{g} 1 \mathrm{ml}$ ph f n s

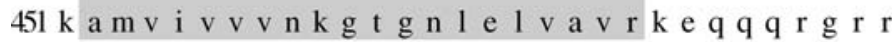
481 e e e e dedee e e g n r e v r r y t a r l ke g d v f 511 i mpa a h p a i n s s e $1 \mathrm{~h} 1 \mathrm{lg}$ f $\mathrm{g}$ i na e n h r 541 i f 1 a g d kdnvi d q i e kqakd l a f p g s g e q v 571 e k l i kn q e s h f v s a r p q s q q s p s s p e k $601 \mathrm{~s} p$ e k e d q e e n q g g k p $11 \mathrm{~s} \mathrm{i} 1 \mathrm{kaf} n$

result of N-terminal sequencing as RSPPGERT, which matched the N-terminal sequence of Ara h1 published by de Jong et al. [39]. The reason why the purified Ara h1 does not contain the first 85 residues in $\mathrm{N}$-terminal of clone $\mathrm{P} 41 \mathrm{~B}$ precursor may be due to the incomplete or different post-translational modifications [40].

Production and characterization of antibodies against Ara h1

Anti-Ara h1 polyclonal antibodies were produced in New Zealand White rabbits against two different immunogens. The first immunogen was purified Ara h1, which was utilized in the production of antibodies against the whole Ara h1 molecule, and designated antiAra h1 antibodies (R2307 and R2308). The second immunogen was the synthetic peptide KLH. Selection of the optimal epitope on Ara h1 for the synthetic peptide was based on its predicted antigenicity, IgE-binding affinity, surface probability, and secondary structure. From the epitope prediction data utilizing the amino acid sequence of clone P41B precursor of Ara h1 provided by AnaSpec Inc. (San Jose, CA, USA), the epitope selection was narrowed down to two possible candidates: epitope A (amino acid residues 493-507) and epitope B (amino acid residues 603-615). The predicted data also showed that epitope $\mathrm{B}$ was more antigenic than epitope A. However, in the study of IgE-binding epitopes on Ara h1, epitope A is one of the four immu- nodominant IgE-binding epitopes (amino acid residue 25-34, 65-74, 89-98, and 498-507) on Ara h1 in that they were recognized by serum from more than $80 \%$ of peanut allergic patients and bound more $\operatorname{IgE}$ than any other Ara h1 epitope [41]. Moreover, from the structural analysis of the IgE-binding site on Ara h1 published by Shin et al. [42], epitope A was predicted as the $\beta$-strand on the outer surface of C-terminal domain of Ara h1, but epitope B was unpredictable. After all of these comparisons, epitope A was selected to produce the synthetic peptide $\mathrm{KLH}$, and antibodies raised against this immunogen were designated anti-peptide antibodies (R2149 and R2150).

The specificity of these four batches of antibodies was determined by immunoblotting (Western Blot) against the total peanut proteins $(0.5 \mu \mathrm{g} / \mathrm{lane})$. In this assay, all four batches of antibodies showed high specificity to Ara $\mathrm{h} 1$, since these antibodies did not react with other peanut proteins from the crude extract of peanuts (Fig. 4a). However, the highest immunoreaction was observed with anti-peptide antibody R2150. To estimate antibody affinity to Ara h1, the same four batches of antibodies were tested in an indirect ELISA. In this assay, the purified Ara h1 was coated in wells (50 ng/well) of microtiter plates. Antibodies against Ara h1 were added to the coated wells, washed, and then detected by HRPconjugated goat anti-rabbit IgG. Similar to the Western Blot, in this assay, anti-peptide antibodies had higher affinity to Ara h1 than anti-Ara h1 antibodies (Fig. 4b). For the Western Blot and ELISA, the order of the 



Fig. 4 Western blot (a) and indirect-ELISA (b) of peanut proteins incubated with four batches of antibodies against Ara h1. Western Blot was performed with total peanut proteins $(0.5 \mu \mathrm{g} /$ lane $)$, and ELISA with the purified Arah1 (50 ng/well). (In panel A, first column contained pre-stained protein standards; second column contained total peanut proteins stained with Coomassie brilliant blue $\mathrm{G} 250$ )

antibody's immunoactivity to Ara h1 was R2150 > R2149 > R2308 > R2307.

Optimization of the lateral flow assay

The sensitivity of the lateral flow assay for detecting peanut allergens was investigated by studying the effects of immobilized antibody, the nature of nitrocellulose membrane, the type of blocking solution and conjugate pad, and the antigen molar percentage on the liposomal surface. To optimize a lateral flow assay for detection of Ara h1, the first approach is to select an antibody showing the highest immunoactivity to Ara h1 from four batches of antibodies (R2307, R2308, R2149, and R2150). The results from Western Blot clearly showed that all four batches of antibodies had high specificity to Ara h1, since they did not show any cross-activity to other crude peanut proteins (Fig. 4a). No decision on selecting a proper batch of antibodies was made based on antibody specificity. Therefore, all batches of antibodies were tested on the NC membrane for selecting the optimal capture antibody in the test strip preparation. The antibodies were individually immobilized on the test line of the test strips (Fig. 1), and their affinity to Ara h1 was tested in the presence of Ara h1-tagged liposomes used as the detector reagent. The higher signal on the test line means the greater affinity the antibody has to Ara h1. In this assay (Fig. 5), anti-Ara h1 antibodies (R2307 and R2308) had higher affinity to Ara h1 than anti-peptide antibodies (R2149 and R2150). Their affinity order to Ara h1 was R2307 > R2308 > R2150 $>$ R2149. Data from this test strip assay showed contradictory results to the indirect ELISA or Western Blot, where the anti-peptide antibodies had higher affinity to Ara h1 than anti-Ara h1 antibodies. There are two possible explanations for this contradiction. The first explanation is based on the different physicochemical conditions between the lateral flow assay and conventional immunoassays (Western Blot and ELISA). The stability of the antibody was different in solution (Western Blot or ELISA) compared to that immobilized on the dry NC membrane surface (Lateral flow assay). During conventional immunoassays, antibodies remain in solution. In the test strip preparation and storage, antibodies were subjected to additional physical conditions such as dispensing and drying. These could affect antibody stability and thus result in reduced immunoactivity. Therefore, the stability of immobilized antibodies becomes a key consideration in antibody selection for the test strip preparation [40]. The second possible explanation is that since the anti-Ara h1 antibodies (R2307 and R2308) were raised against the whole Ara h1 molecule, they could recognize more epitopes per Ara h1 than anti-peptide antibodies (R2149 and R2150), which were raised against only 15 amino acids of Ara h1. The antibody that binds more epitopes per analyte may capture more analytes compared to the antibody that only recognizes a small portion of an analyte. Among these four batches of antibodies, anti-Ara h1 antibody (R2307) had the highest affinity to the antigen, and was chosen for the further assay development.

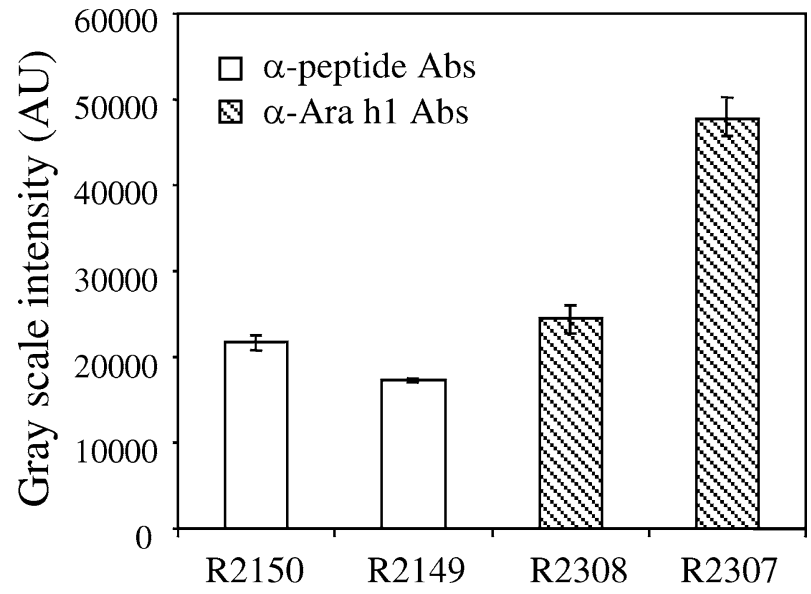

Fig. 5 Immunoassay of the two anti-peptide antibodies (R2150 and R2149) and two anti-Ara h1 antibodies (R2038 and R2037) with Ara h1-tagged liposomes as the detector reagent on the nitrocellulose membrane test strip. Antibody $\left(4 \mu \mathrm{g} \mathrm{cm}^{-1}\right)$ was coated in the test line on the strip, and the signal intensity of the immunoassay was determined by gray scale intensity (GSI) with a computer-scanning program 
The sensitivity of a lateral flow assay is dependent on the signal intensity of the test line, and the signal intensity is affected by the coating buffer that is used for dilution of the capture reagent, such as antibodies. The coating buffer can influence the antibody absorption on the membrane, the antibody immunoactivity (specificity and stability), and the flow properties of the membrane [43]. To get the optimal coating buffer, the ingredients of the coating buffer were investigated. Generally, the presence of ions in the coating buffer can increase the solubility of antibodies; however, ions also interfere with electrostatic interactions between antibodies and membranes, and thus have an effect on assay sensitivity [44]. Two buffer systems were examined to investigate the ion effect: phosphate buffer (PB: $10 \mathrm{mM} \mathrm{Na} 2 \mathrm{HPO}_{4}$ adjusted to $\mathrm{pH}$ 7.5) and phosphate-buffered saline (PBS: $10 \mathrm{mM}$ $\mathrm{Na}_{2} \mathrm{HPO}_{4}$ with $150 \mathrm{mM} \mathrm{NaCl}$ adjusted to $\mathrm{pH} 7.5$ ). Combinations of PB or PBS solution with two co-precipitation agents (methanol and Tween-20) were used to evaluate assay sensitivity. Use of small amounts of coprecipitation agents can decrease protein solubility but promote the adsorption of the protein onto the $\mathrm{NC}$ membrane [45]. The concentration of methanol and Tween-20 were $5 \%(\mathrm{v} / \mathrm{v})$ and $0.002 \%(\mathrm{v} / \mathrm{v})$, respectively. To avoid the lysis of liposomes, only a low concentration of Tween-20 is used. As shown in Fig. 6, all combinations with additives gave higher signal intensities of the PB system compared with those of the PBS system. Additionally, without any additives the signal intensity of PB system was comparable to that of PBS system. Data from this experiment indicated that the presence of ions could interfere with the binding between antibodies and the NC membrane, and thus reduce the antibody coating efficiency. The highest signal intensity of the test

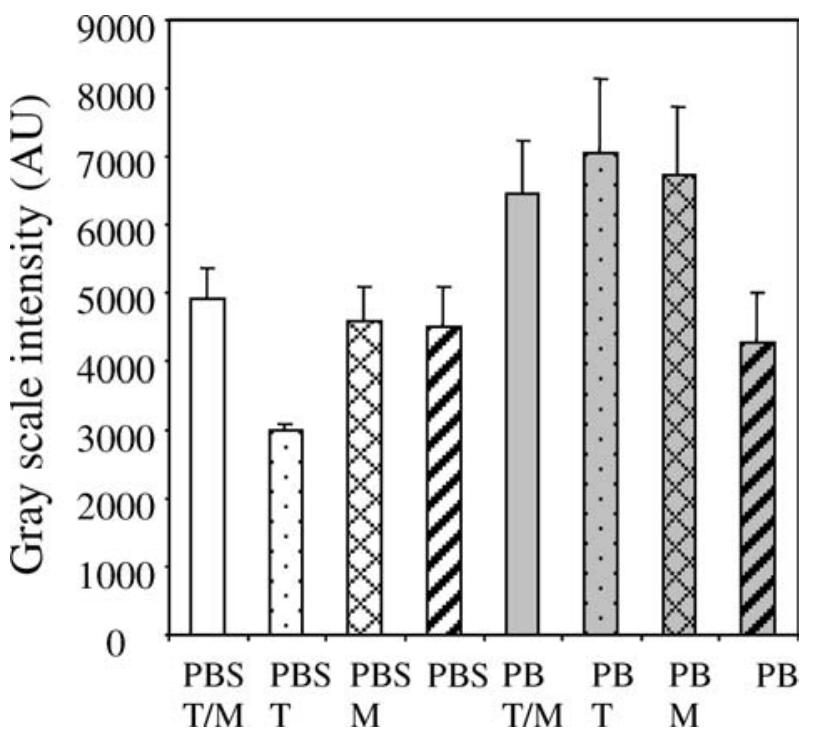

Fig. 6 Effect of the coating buffer composition on the immunoassay of the Ara h1-tagged liposomes with anti-Ara hl antibody (R2307). Antibody was coated with different coating buffers on NC membrane with density as $4 \mu \mathrm{g} \mathrm{cm}^{-1}$. (PBS: $10 \mathrm{mM}$ sodium phosphate, $150 \mathrm{mM} \mathrm{NaCl}, \mathrm{pH}$ 7.5; PB: $10 \mathrm{mM}$ sodium phosphate, $\mathrm{pH}$ 7.5; rom $T$ : $0.002 \%$ (v/v) Tween 20; rom $M: 5 \%$ (v/v) methanol) line was obtained by using $10 \mathrm{mM}$ phosphate buffer with $0.002 \%$ Tween-20 (v/v). Addition of methanol, Tween-20, or both to the PB solution had a significantly enhanced effect on the signal intensity compared with only the PB solution. Adequate drying of the membrane after protein application is an important practice for ensuring the long-term stability of the protein-membrane bond [46]. Therefore, after drying, the antibodycoated membrane was stored in a sealed bag at $4^{\circ} \mathrm{C}$ in the presence of dessicant.

The type of nitrocellulose membrane is the other important factor for developing test strips. The nature of the membrane affects its capillary flow properties, which in turn affects assay sensitivity, assay specificity, and test line consistency. The capillary rate is the speed at which a sample front moves along a membrane strip. Therefore, a membrane with higher capillary rate requires a shorter time to complete an assay. The major goal of this study was to develop a rapid assay, and because of that only membranes with higher capillary rate were chosen to investigate their effects on assay sensitivity. After the evaluation of the NC membranes [AE 99, AE 100, FF 85, Prima 85 (S\&S), HF120 (Millipore)], the Prima 85 membrane completed the assay with the shortest time, but it showed the broadest test line. This caused a loss in signal intensity and a decrease in assay sensitivity. In a competitive lateral flow assay, the assay sensitivity is defined as the lowest concentration of analyte that causes a measurable decrease of the signal intensity of the test line. Among the AE 99, AE 100, FF 85, and HF120 NC membranes, the lowest concentration of Ara h1 in the sample to produce a decrease in the signal intensity was observed when using the AE 100 as the NC membrane. Therefore, AE 100 was the most appropriate $\mathrm{NC}$ membrane for this assay development.

After immobilizing anti-Ara h1 antibodies on AE 100 $\mathrm{NC}$ membranes, the reactive groups on the membrane must be blocked. In this assay, the blocking solution was applied to the conjugate pad instead of to the NC membrane. To find the optimal conjugate pad, several materials were tested: non-woven $8-\mathrm{S}, 12-\mathrm{S}$, and $16-\mathrm{S}$, glass fiber 33 Glass, AccuFlow P, AccuFlow G, AccuFlow Plus G (S\&S), and glass fiber paper F075-17 (Whatman). Each pad was evaluated by comparing the signal intensity of the test lines, the distribution of Ara h1-tagged liposomes on the pad, and the amount of Ara h1-tagged liposomes remaining on the pad after running the assay. The best result was achieved by using nonwoven 12-S conjugate pad (S\&S). Since the components of the blocking solution can also affect assay sensitivity by changing the capillary rate, or by blocking the interaction between immobilized antibodies and analytes, different combinations of frequently used blocking materials were investigated to get the optimal blocking solution. These materials were either "protein based", such as BSA, gelatin, casein, and goat serum, or "nonprotein-based", such as PVP (MW $10 \mathrm{kDa}$ ), PVA [poly(vinyl alcohol), MW $16 \mathrm{kDa}$, Tween-20, and Triton $\mathrm{X}-100$. The results showed that there were no 
obvious differences in signal intensity of the test line between using PVP and PVA, or between using Triton $\mathrm{X}-100$ and Tween-20. Furthermore, blocking buffers with different concentrations of Triton X-100 [0.002, 0.02 , and $0.2 \% \mathrm{v} / \mathrm{v}]$ were tested, and signal intensity decreased with the increasing concentration of Triton X100 . Higher concentrations $(0.02$ and $0.2 \%)$ of Triton X100 could induce the lysis of liposomes and therefore produce a smaller number of intact liposomes captured on the test line. A comparison of 20 different blocking solutions showed the highest signal intensity, and significantly less background on the strips was obtained with the 12-S conjugate pad blocked with the mixture of $5 \mathrm{mM}$ sodium tetraborate $(\mathrm{pH} 8.0), 4 \%$ BSA, $3 \%$ goat serum, $1 \% \mathrm{PVP}$, and $0.002 \%$ Triton X-100.

The affinity of Ara h1-tagged liposomes, used as the detector reagent, for the immobilized antibodies was the final important factor needing to be optimized. The affinity between antibody and Ara h1-tagged liposome was affected by the molar percentage $(\mathrm{mol} \%)$ of Ara h1 on the liposomal surface. Four different Ara h1 concentrations were tested: $2,1,0.4$, and $0.1 \mathrm{~mol} \%$. The signal intensity of the test line was proportional to the molar percentage of Ara h1 on the liposome surface. However, using 1 or $2 \mathrm{~mol} \%$ of Ara h1-tagged liposomes required a higher concentration of Ara h1 in the sample to perform the competitive assay, and this resulted in a decrease of the assay sensitivity. In addition, the liposome with $0.1 \mathrm{~mol} \%$ of Ara h1 on the surface showed very weak signal in the absence of Ara h1 in the sample, so it was not an appropriate detector reagent for this assay. Therefore, $0.4 \mathrm{~mol} \%$ of Ara $\mathrm{h} 1$ on the liposomal surface was selected for use as detector reagent in this competitive lateral flow assay. Moreover, liposomes are very stable structures. In a previous study, no significant changes in liposome stability was observed when stored at $4^{\circ} \mathrm{C}$ over 9 months [47].

\section{Assay performance}

The assay is based on the competition between Ara h1 in the sample and Ara h1 tagged to liposome surface for binding to the limited amount of anti-Ara $\mathrm{h} 1$ antibodies immobilized in the test line of the NC membrane strips. When the test strip is first incubated with the sample, Ara h1 molecules from the sample migrate through the test strip, and are captured by antibodies in the test line. After all of the sample solution migrates into the strip, Ara h1-tagged liposomes are added into the tube, migrate through the same path as the free Ara h1 molecules, and are captured by the remaining immobilized antibodies with available binding sites. However, the more Ara h1 present in the sample, the less antigenbinding sites of the immobilized antibodies are available for capturing the Ara h1-tagged liposomes. Therefore, the signal intensity of the test line is inversely proportional to the amount of Ara hl in the sample. The LOD of this competitive lateral flow assay was obtained from the dose-response curve (Fig. 7). The signal intensities of the test lines were measured as the gray scale intensity (GSI) by densitometry scanning. The value of LOD was calculated as the concentration equivalent to the mean of the blank Ara h1 samples minus three standard deviations (SD). From the dose-response curve, a 5parameter sigmoidal function was described by the following equation:

$y=3592+\frac{6865.5865}{\left[1+\mathrm{e}^{-\left[\frac{x-3.147}{-0.3156}\right]}\right]^{1.535}}$

For the data plotted, this function has an $R^{2}$ value as 0.9991 , and from this equation the LOD value was calculated as $450 \mathrm{ng} \mathrm{mL} \mathrm{mL}^{-1}$ of Ara h1. The dynamic range of this dose-response curve is approximately between $10^{2}$ and $10^{4} \mathrm{ng} \mathrm{mL}{ }^{-1}$. In addition, the visual detection limit of this assay was about $1 \mu \mathrm{g} \mathrm{mL}^{-1}$ based on the significant decrease of signal intensity of the test line by observation at this concentration of Ara h1. At higher concentrations of Ara h1 $\left(>10 \mu \mathrm{g} \mathrm{mL}^{-1}\right)$, the test line could not be visually observed. Therefore, the visually determined range of this assay is about $1-10 \mu \mathrm{g} \mathrm{mL}^{-1}$ of Ara $\mathrm{h} 1$ in buffer. When the assay is performed properly, the control line is always visible above the test line.

\section{Conclusions}

This study has developed and optimized a rapid and sensitive lateral flow assay for the detection of peanut

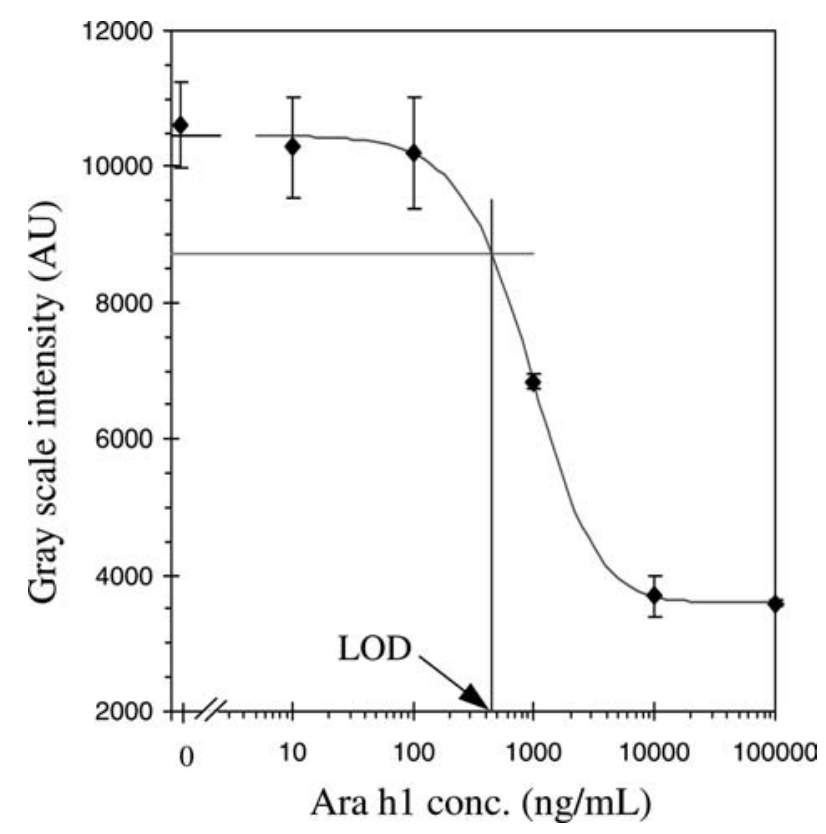

Fig. 7 A competitive lateral flow assay with a serial dilution of Ara h1 $\left(0,1 \times 10^{1} ; 1 \times 10^{2} ; 1 \times 10^{3} ; 1 \times 10^{4} ; 1 \times 10^{5} \mathrm{ng} \mathrm{mL}^{-1}\right)$. Doseresponse curve for Ara hl samples generated from the test strip assay by gray scale intensity (GSI) measurement. A 5-parameter sigmoidal function $\left(R^{2}=0.9991\right)$ was calculated from this doseresponse curve 
allergens using Ara h1-tagged liposomes as the detector reagent. The final optimized format of the test strip used AE100 (S\&S) as the NC membrane, non-woven 12-S (S\&S) as the conjugate pad, and type 900 cotton linter paper (S\&S) as the absorbent pad. Among four batches of developed antibodies against Ara h1, anti-Ara h1antibody (R2307) was selected based on its highest immunoactivity to Ara h1 in the LFA assay and no crossreactivity to other crude peanut proteins. It was coated at $4 \mu \mathrm{g} \mathrm{cm}^{-1}$ on $\mathrm{NC}$ membrane with a coating buffer consisting of $10 \mathrm{mM}$ phosphate buffer $(\mathrm{pH} \mathrm{8.0)}$ with $0.002 \%$ Tween 20. Ara h1-tagged liposomes with $0.4 \mathrm{~mol} \%$ Ara $\mathrm{h} 1$ on the surface were used as the detector reagent. This assay is rapid (completed within $30 \mathrm{~min}$ ), and easy to use by either visual determination or densitometry measurement of the test line using computer scanning or a handheld reflectometer.

From the Ara h1 dose-response curve, the LOD of this assay was determined to be approximately $450 \mathrm{ng}$ $\mathrm{mL}^{-1}$ of Ara h1 in buffer. Since Ara h1 normally comprises about $15 \%$ of total peanut proteins, this assay can theoretically detect peanut proteins contamination above $3.0 \mu \mathrm{g} \mathrm{mL}^{-1}(3 \mathrm{ppm})$. This number is comparable to the sensitivity $(5-10 \mathrm{ppm})$ of commercial lateral flow assay kits. Comparing the sensitivity of this lateral flow assay to ELISA [10] or PCR assays [17, 18], this lateral flow assay has higher LOD and simply provides a qualitative yes/no answer. On the other hand, this lateral flow assay has the advantages of shorter assay time, operational simplicity, and fewer requirements for equipment compared to ELISA and PCR. Therefore, this lateral flow assay is more suitable for on-site detection such as in food processing and distribution facilities.

This study successfully demonstrated the potential of using the allergen-tagged liposomes in a competitive lateral flow assay for the detection of food allergens. Future studies will focus on testing this assay in a variety of different food matrices to develop sample preparation protocols, accurately determine the LOD in various food samples, and focus on directly immobilizing liposomes on the conjugate pad to further simplify the entire assay procedure.

Acknowledgements The authors thank Dr. Antje Baeumner and Dr. Randy Worobo of Cornell University for their helpful suggestions on this research, and for the Vitasoy \& Lo Fellowship awarded to Hsio-Wei Wen.

\section{References}

1. Sicherer SH (2002) Ann Allergy Asthma Immunol 88:350-361

2. Sicherer SH, Munoz-Furlong A, Burks AW, Sampson HA (1999) J Allergy Clin Immunol 103:559-562

3. Tariq SM, Stevens M, Matthews S, Ridout S, Twiselton R, Hide DW (1996) BMJ 313:514-517

4. Emmett SE, Angus FJ, Fry JS, Lee PN (1999) Allergy 54:380385

5. Sampson HA (1996) BMJ 312:1050-1051
6. Grundy J, Matthews S, Bateman B, Dean T, Arshad SH (2002) J Allergy Clin Immunol 110:784-789

7. Hourihane JO'B, Kilburn SA, Nordlee JA, Hefle SL, Taylor SL, Warner JO (1997) J Allergy Clin Immunol 100:596-600

8. Schappi GF, Konrad V, Imhof D, Etter R, Wuthrich B (2001) Allergy 56:1216-1220

9. Poms RE, Klein CL, Anklam E (2004) Food Addit Contam 21:1-31

10. Pomes A, Helm RM, Bannon GA, Burks AW, Tsay A, Chapman MD (2003) J Allergy Clin Immunol 111:640-645

11. Holzhauser T, Dehne LI, Hoffmann A, Haustein D, Vieths S (1998) Eur Food Res Technol 206:1-8

12. Blais BW, Phillippe LM (2000) Food Agric Immunol 12:243248

13. Yunginger JW, Gauerke MB, Jones RT, Dahlberg MJE, Ackerman SJ (1983) J Food Prot 46:625-628

14. Keating MU, Jones RT, Worley NJ, Shively CA, Yunginger JW (1990) Allergy Clin Immunol 86:41-44

15. Stephan O, Möller N, Lehmann S, Holzhauser T, Vieths S (2002) Eur Food Res Technol 215:431-436

16. Shefcheck KJ, Musser SM (2004) J Agric Food Chem 52:27852790

17. Hird H, Lloyd J, Goodier R, Brown J, Reece P (2003) Eur Food Res Technol 217:265-268

18. Stephan O, Vieths S (2004) J Agric Food Chem 52:3754-3760

19. R-Biopharm AG. Available at: http://www.r-biopharm.com. Accessed April 2005

20. Tepnel BioSystems Ltd (2005) Available at: http://www.tepnel.com. Accessed April 2005

21. Verheijen R, Stouten P, Cazemier G, Haasnoot W (1998) Analyst 123:2437-2441

22. Leung W, Chan P, Bosgoed F, Lehmann K, Renneberg I, Lehmann M, Renneberg R (2003) J Immunol Methods 281:109-118

23. Neogen Corporation (2005) Available at: http://www.neogen.com. Accessed April 2005

24. Bannon GA, Besler M, Hefle SL, Hourihane JO'B, Sicherer SH (2000) Internet Symp Food Allergens 2:87-123 (http:// www.food-allergens.de/)

25. Maleki SJ, Kopper RA, Shin DS, Park CW, Compadre CM Sampson H, Burks AW, Bannon GA (2000) J Immunol 164:5844-5849

26. Koppelman SJ, Bruijnzeel-Koomen CA, Hessing M, de Jongh HH (1999) J Biol Chem 274:4770-4777

27. Lasch L, Weissing V, Brandl M (2003) In: Torchilin VP, Weissig V (eds) Liposomes: a practical approach. Oxford University Press, New York, pp 3-29

28. Ahn-Yoon S, DeCory TR, Durst RA (2004) Anal Bioanal Chem 378:68-75

29. Plant AL, Brizgys MV, Locasio-Brown L, Durst RA (1989) Anal Biochem 176:420-426

30. Shevchenko A, Wilm M, Vorm O, Mann M (1996) Anal Chem 68:850-858

31. Laemmli UK (1970) Nature 227:680-685

32. Towbin H, Staehelin T, Gordon J (1979) Proc Natl Acad Sci USA 76:4350-4354

33. DeCory TR, Durst RA, Zimmerman SJ, Garringer LA, Paluca G, DeCory HH, Montagna RA (2005) Appl Environ Microbiol 71:1856-1864

34. Siebert STA, Reeves SG, Durst RA (1993) Anal Chim Acta 282:297-305

35. Bartlett GR (1959) J Biol Chem 234:466-468

36. Johns CO, Jones DB (1916) J Biol Chem 28:77-87

37. Burks AW, Williams LW, Helm RM, Connaughton C, Cockrell G, O'Brien T (1991) J Allergy Clin Immunol 88:172-179

38. Burks AW, Cockrell G, Stanley JS, Helm RM, Bannon GA (1995) J Clin Invest 96:1715-1721

39. de Jong EC, Van Zijverden M, Spanhaak S, Koppelman SJ, Pellegrom H, Penninks AH (1998) Clin Exp Allergy 28:743-751

40. Spremulli L (2000) In: Buchanan BB, Gruissem W, Jones RL (eds) Biochemistry\& molecular biology of plants. American Society of Plant Physiologists, MD, pp 412-454 
41. Burks AW, Shin D, Cockrell G, Stanley JS, Helm RM, Bannon GA (1997) Eur J Biochem 245:334-339

42. Shin DS, Compadre CM, Maleki SJ, Kopper RA, Sampson H, Huang S K, Burks AW, Bannon GA (1998) J Biol Chem 273:13753-13759

43. Anon (2002) Rapid lateral flow test strips. Millipore Corporation, MA, USA
44. Jones KD (1999) In Vitro Diag Technol 5:32-41

45. Schneider Z (1980) Anal Biochem 108:96-103

46. Harlow E, Lane D (eds) (1988) Antibodies: A laboratory manual. CSHL Press, NY, USA

47. Ahn-Yoon S, DeCory TR, Baeumner AJ, Durst RA (2003) Anal Chem 75:2256-2261 